\title{
Chapter 12 \\ Access to Social Protection by Immigrants, Emigrants and Resident Nationals in Morocco
}

\author{
Abderrahim Oulidi and Keivan Diakité
}

\subsection{Overview of the Welfare System and Main Migration Features in Morocco}

This chapter aims to discuss the legal framework regulating Morocco's welfare system and the access of national residents, non-national residents, and non-resident nationals to social benefits across five policy areas: unemployment, health care, family benefits, pensions, and guaranteed minimum resources.

The current Moroccan welfare system can be better understood when tracing the historical development of its key components. Like in many African countries, the social security in Morocco until the protectorate was mainly based on a traditional form of solidarity and family mutual assistance (Reimat 1997). Occupational groups, such as the traditional trade guilds, developed a solidarity system that guaranteed care in case of accidents or illness to everyone. ${ }^{1}$ It was only after the establishment of the French protectorate that the Moroccan state started to adopt specific legislation in the field of social protection- especially pensions. However, this legislation was mainly intended to protect the needs of French workers and officials

\footnotetext{
${ }^{1}$ « Le système de retraite au Maroc » Revue Al Maliya, n40 march 2007, p 22. Available here: http://www.finances.gov.ma/Maliya\%20tawassol/file_220807_151728869.pdf. Accessed 26 March 2020.
}

\footnotetext{
A. Oulidi $(\triangle)$

Studies and Risk Management Department, Solidarity Fund Against Catastrophic Events, Rabat, Morocco

K. Diakité

Louvain Institute of Data Analysis and Modeling in Economics and Statistics (LIDAM), Louvain-La-Neuve, Belgium
} 
residing in Morocco. In 1917, the protectorate's administration created the Moroccan Provident Fund (CPM) with an optional membership. Similarly, several institutions were created to respond to the needs of different professional groups of French residents covering mainly the workers' compensation scheme managed by private insurance companies, the pension scheme for civil servants, the family allowance scheme financed by European employers, and the pension plan of the European high officials.

\subsubsection{Main Characteristics of the National Social Security System}

The different components of the Moroccan social protection system have been developed in a rather fragmented manner over a very long period of time. The current system consists of a contributory scheme (the National Social Security Fund, $\mathrm{CNSS}^{2}$; the National Fund of Social Welfare Organisations, CNOPS ${ }^{3}$; the Moroccan Pension Fund, CMR; the group retirement allowance plan, RCAR); a partially contributory system (the Medical Assistance Plan, RAMED ${ }^{4}$ ) and a non-contributory system (programs for vulnerable populations such as "Tayssir", "Kafala", or the National Initiative for Human Development, INDH ${ }^{5}$ ). The system covers employees from all public sectors and a large part of private sector employees, ${ }^{6}$ by providing them protection against the risks associated to maternity, invalidity, old age, survival, death, unemployment, and family.

Compulsory social security schemes fulfil an important function of risk coverage and financial transfers in the form of family allowances and income replacement in the form of sickness and maternity benefits, and through the pension scheme (oldage, invalidity and survivors). There are several management bodies: CNOPS manages the public scheme and students; RCAR manages the pensions of state employees, local authorities and public institutions subject to the financial control of the state; CMR manages the pensions of the civilian and military state personnel; and the CNSS manages the private scheme. Medical coverage based on a noncontributory scheme has also been put in place for the poorest population including migrants and refugees (the convention has been ratified, but not yet implemented). They will be part of the Medical Assistance Scheme RAMED, which will be managed by the National Health Insurance Agency (ANAM).

\footnotetext{
${ }^{2}$ Caisse Nationale de Securité Sociale, http://www.cnss.ma/fr. Accessed 26 March 2020.

${ }^{3}$ Caisse Nationale des Organismes de Prévoyance Sociale, http://www.cnops.org.ma. Accessed 22 March 2020.

${ }^{4}$ Régime d'assistance médicale, http://www.ramed.ma. Accessed 26 March 2020.

${ }^{5} \mathrm{http}: / /$ www.indh.ma. Accessed 26 March 2020.

${ }^{6}$ Morocco now has 3.8 million employees in the private sector. About 600,000 of them are not declared by their employers. Source: www.cnss.ma/fr/content/chiffres-clés-1. Accessed 22 March 2020.
} 
The Moroccan pension system is currently based on four schemes. Three of them are mandatory and managed by public institutions: two schemes cover public sector employees (CMR and RCAR) and the third one covers private sector employees via the CNSS. A fourth (optional) scheme is aimed at private sector employees (CIMR). Non-salaried workers (traders, craftsmen, individuals with liberal professions, farmers, and fishermen) cannot join any of these schemes, although Law No. 99-15 of December 2017 proposed the creation of a pension plan for these workers. Also, there is no non-contributory pillar of solidarity in Morocco and the system covers only $40 \%$ of the employed labour force.

As for financing, the contributory plans are financed by employers' contributions, state contribution, donations and any other resources assigned to basic compulsory retirement insurance plans under legislation or special regulations. The four pension plans are also financed by the interest generated by their reserve funds. RAMED is financed by the state, local collectivises, tax revenue, donations, other resources assigned to basic compulsory health insurance plans and flat-rate contributions from vulnerable populations. Since its entry into force in 2006, the CNSS manages the compulsory health insurance (AMO) for private sector employees subject to the Moroccan social security scheme. Recipients of a minimum pension (500 dirhams per month) and people with an annual income of less than 5.650 dirhams per person are covered by RAMED.

\subsubsection{Migration History and Key Policy Developments}

During the last decades, Morocco has put in place several initiatives aiming to ensure the social protection of mobile individuals, including foreigners residing in Morocco and Moroccan nationals residing abroad. Bilateral social security agreements have been signed with Algeria, Belgium, Canada, Denmark, Germany, Egypt, Spain, France, Libya, the Netherlands, Luxembourg, Portugal, Quebec, Romania, Sweden, and Tunisia; and different conventions have been adopted aiming to make the living conditions of foreign residents meet equal standards as for Moroccan citizens.

Morocco's special historical-cultural relationship with West Africa is reflected in the conditions of access to the territory enjoyed by citizens of different countries. While these facilities also concern nationals of European countries, Morocco has in recent years made a strategic revaluation of its diplomatic, commercial, political and security relations with French-speaking West African states. The deployment of various programs has allowed for closer ties between these states and Morocco in the framework of bilateral and international cooperation. The limits and challenges that Morocco faces as a link between Europe and Africa have been quickly emerging, especially given the situation of sub-Saharan migrants who transit Morocco to reach Europe. If for some foreigners, Morocco is actually seen as a transit country in their journey to Europe, for others, it is also and above all a country of immigration. 
Over the years, Morocco has become a destination country for different types of immigration, of various geographical origins (Europe, Africa and elsewhere), permanent or limited in time. Officially, about 84,000 foreigners are currently registered as living in Morocco $^{7}$ (the Moroccan population is 36 million people). The majority of foreigners residing in Morocco come from African countries $(41.6 \%)$ and European countries (40\%). Among the most represented nationalities, the French come first $(25.4 \%)$, followed by Senegalese $(7.2 \%)$, Algerians $(6.8 \%)$ and Syrians (6.2\%). $15.2 \%$ of foreigners come from Asian countries $(82.8 \%$ from the Middle East) and $3.2 \%$ from other continents. The advantages and attractions offered by Morocco as a host country are geographical, economic, linguisticcultural, but also political. As a politically stable country, in the process of economic and social modernization, offering geographical and linguistic-cultural proximity to Europe, Morocco attracts a potentially large target group of foreigners wishing to emigrate.

Nowadays, a foreign employee of the private sector can benefit from CNSS services in the same way as a Moroccan citizen. Furthermore, a framework agreement has been recently adopted to allow immigrants and refugees to access the Medical Assistance Scheme (RAMED). However, migrants and refugees still do not have access to RAMED benefits as technical problems between the Ministry of Interior, the Ministry of Moroccans living abroad, and the National Health Insurance Agency delayed the publication of affiliation cards to gain access to medical benefits for migrants and refugees.

According to the OECD (2017) report on Moroccan emigrants, it is estimated that just over 4.3 million Moroccans live abroad. Given that the total population of Morocco is 36 million people, the estimated share of non-resident Moroccans corresponds to $11 \%$ of the population residing in Morocco. It is therefore not a coincidence that a Ministry in charge of Moroccans Residing Abroad (MRE) ${ }^{8}$ exists in Morocco. However, the historical reasons for migration and the direction of migration flows differ. As an example, the labour agreements that Morocco concluded with Belgium and France in the early 1960s led to a growing outflow (until the 1970s - then, thanks to family reunification, until the 1990s) of Moroccan migrants residing in France and Belgium, particularly manual labourers settling there and raising children. The recent outflow of Moroccans to the Gulf countries (especially Saudi Arabia) can also be mentioned.

As shown in Figs. 12.1 and 12.2, the main destination of Moroccan emigrants is Europe. $86 \%$ of Moroccans residing abroad live in France, Spain, Italy, Belgium, and the Netherlands. The second destination is North America, where $7.5 \%$ of the emigrant population is found, followed by Arabic and Middle East countries that host around for $4.5 \%$ of the emigrant population.

\footnotetext{
${ }^{7}$ High Commission for Planning report (2018)

${ }^{8}$ Website of the Ministry of Moroccans living abroad (MRE). https://marocainsdumonde.gov.ma/. Accessed 26 March 2020.
} 


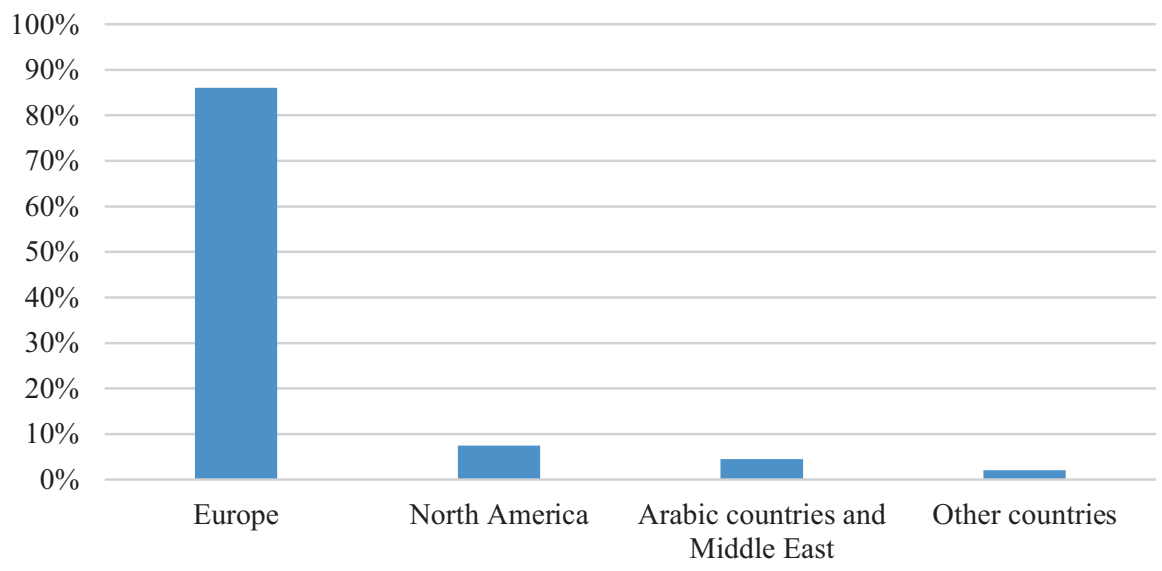

Fig. 12.1 Destinations of Moroccans residing abroad, 2018. (Source: Ministry of Moroccans living abroad (MRE))

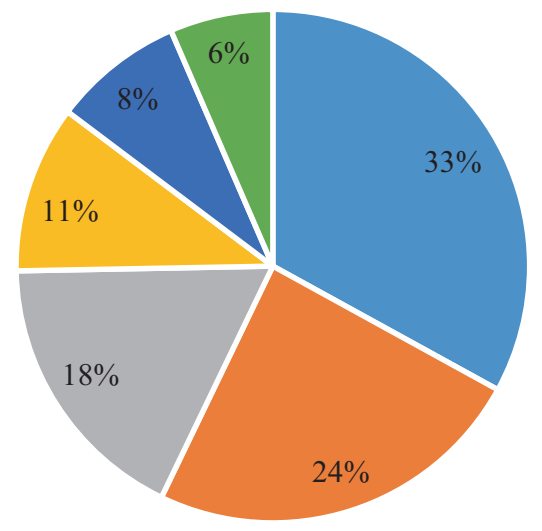

- France $\quad$ Spain $\|$ Italy $\approx$ Belgium $\quad$ Netherlands $=$ others

Fig. 12.2 Main European countries of destination of Moroccan emigrants. (Source: Ministry of Moroccans living abroad (MRE))

More than half of Moroccan emigrants in Europe mention family reasons as reasons for migration, whereas work is the second most common reason. This flow includes a considerable number of seasonal workers. 58\% of Moroccan emigrants have low levels of education (first cycle of secondary education), whereas emigrants with a high level of education are proportionally more numerous in North America (two-thirds of Moroccan emigrants are graduates of higher education) (OECD 2017). 


\subsection{Migration and Social Protection in Morocco}

CNSS affiliates, whether national citizens or foreigners residing in Morocco, are protected in terms of access to social benefits. To become a CNSS affiliate, a person must be employed in Morocco. The entitlement to AMO benefits is conditioned by the justification of 54 days of prior contribution for a period of six months. Affiliation is a legal obligation of every employer who is required to join CNSS no later than 30 days after the first employee is hired, to regularly report to the CNSS the monthly amount of wages paid and the number of days worked by their employees.

Foreigners residing in Morocco are subject to the same conditions as nationals and receive the same benefits. Moroccans living abroad cannot voluntarily enter the Moroccan social security scheme if they were not affiliated before moving abroad. However, some of the acquired rights are subject to exportability, including the oldage pension, the disability pension, or maternity benefits. Since the 1960s, social security benefits that are subject to exportability are paid to affiliates even if there is no bilateral social security agreement between Morocco and their respective countries of residence. The only condition is to show a proof of residence in the new country. Moreover, it is also worth mentioning that Morocco is part of several regional integration organisations, including the African Union (UA), the Arab Maghreb Union (UMA) and the Community of Sahel-Saharan States (CEN-SAD). However, none of these regional integration schemes has made specific efforts to ensure the social protection of intra-regional migrants or to facilitate their access to specific benefits in the countries of residence.

The next section of the chapter discusses the eligibility conditions for accessing social benefits for national residents, non-national residents and non-resident nationals; and it further highlights the specificities of each policy area.

\subsubsection{Unemployment}

The National Social Security Fund (CNSS) provides employees who involuntarily lose their jobs and are actively seeking for work a minimum income called Loss of Employment Compensation (IPE). This allowance is financed by employees $(0.19 \%$ of salary capped at 6.000 dirhams) and employers ( $0.38 \%$ of salary capped at 6.000 dirhams). The benefit is granted for up to 6 months to employed workers affiliated to CNSS. Resident nationals and foreigners can claim this allowance under the same conditions. To claim the benefit, individuals must have accumulated 780 days of salary declarations during the last 36 months preceding the date of job loss, including 260 days during the last 12 months preceding this date. The monthly amount is equal to $70 \%$ of the reference salary (average monthly salary declared for 
the last 36 months), without exceeding the amount of the statutory minimum wage. ${ }^{9}$ Those who receive the benefit must register with the National Agency for Promotion of Employment and Skills (ANAPEC) and actively search for work (although the job search is never checked). $25 \%$ of people registered for the unemployment allowance have either resumed their job or found a new one (CNSS 2018).

\subsubsection{Health Care}

The medical coverage system in Morocco consists of a basic system including the Mandatory Health Insurance (AMO) and the Medical Assistance Plan (RAMED). ${ }^{10}$ $\mathrm{AMO}$ is based on the contributory principle and the principle of risk pooling. It provides benefits in kind in case of sickness and cash benefits for sickness and physical invalidity. Membership is compulsory for companies that are subject to the social security scheme and do not have any medical coverage at the date of entry into force of the Mandatory Health Insurance. ${ }^{11}$ Article 14 of the Law 65-00 provides for a period of five years from the decree of application of the law to allow companies to join AMO. However, the application decree has never been released, which leads to the fact that today, 1.27 million private sector employees are not affiliated to the AMO, including 303.000 employees of the public sector. ${ }^{12}$ However, they remained covered by private insurance.

The right to basic health care AMO benefits ${ }^{13}$ for private sector employees is subject to the completion of a contribution period of 54 working days during the six months preceding the care, the actual payment of contributions by the employer, the identification of family members of the insured or pensioner with the CNSS, and the declaration of long and costly diseases at the CNSS. In order for the CNSS to reimburse the care costs (doctors' fees, prescribed medications, etc.), affiliates must submit a health care form filled by their physician. The reimbursement period set by law is three months from the filing date, and a physical medical check can be scheduled as part of the AMO Services. Resident nationals and foreign citizens can access benefits in kind in Morocco under the same eligibility conditions. However, medical care abroad is only reimbursable or covered if the insured person falls ill

\footnotetext{
${ }^{9}$ As of January 1, 2018, the legal minimum wages in Morocco (SMIG) is 13.46 dirhams/hour in the sector of industry, trade and liberal professions. The monthly SMIG is equal to $13.46 \mathrm{MAD} / \mathrm{Hour}$ * 191 Hours/Month = 2570.86 dirhams. Source: http://blog.ojraweb.com. Accessed 26 March 2020.

${ }^{10}$ This scheme, which entered into force on 18 August 2005, was introduced by Law 65.00 on the code of medical coverage.

${ }^{11}$ Article 114 Law 65-00, https://www.cnss.ma/sites/default/files/loi-65-00-amo_0.pdf. Accessed 26 March 2020.

${ }^{12}$ ANAM (2017). Convention de partenariat relative à la production et à la délivrance des cartes d'assistance médicale pour les migrants au Maroc.

${ }^{13}$ The medical coverage taken into account. http://www.cnss.ma/fr/content/que-couvre-lamo. Accessed 26 March 2020.
} 
unexpectedly. In this case, the refund is made on the basis of national pricing, so health benefits in kind are not transferable. Moroccans residing abroad cannot thus claim these benefits from Morocco.

Sickness cash benefits are available only to employees. Both resident nationals and foreigners can claim the sickness allowance under the same conditions. There is no specific requirement of prior residence in the country, although cash benefits do depend on a period of insurance (54 days of contribution during the 6 months preceding the sickness).Sickness allowances are not transferable for nationals living abroad (the benefit is only paid in Morocco during a maximum period of 52 weeks),but individuals who receive sickness benefits can move temporarily abroad if they show up for the medical check in Morocco. However, disability pensions can be transferred abroad if affiliates show a residence certificate. Invalidity pensions are available only to employees, foreigners or nationals. The minimum period of insurance required to become eligible is 3 years. If the invalidity is caused by an accident on the workplace, this condition does not apply and the benefit is automatically granted. The amount of the pension is based on the previous earnings. The invalidity pension is always granted on a temporary basis and it is replaced by an old-age pension when the beneficiary reaches the pensionable age.

The medical assistance scheme is based on the principle of national solidarity for the benefit of the poor population..${ }^{14}$ RAMED only provides benefits in kind. ${ }^{15}$ Based on the principle of solidarity, this scheme has a semi-contributory part financed by a fixed participation of people and households deemed vulnerable. ${ }^{16}$

The Moroccan health care system was initiated under the French protectorate. More than 60 years after independence and despite the progress made since 2002 with the introduction of health insurance schemes for private sector employees, civil servants and the poor, the system is still struggling to comply with the principles of universality, solidarity, and quality of care. In $2016,45.4 \%$ of the population did not have medical coverage. ${ }^{17}$ Self-employed persons are not yet covered by any health social protection scheme, although they account for a third of the Moroccan population. The 98-15 draft law plans to include them in the AMO regime. It will come into force once published in the Official Bulletin.

\footnotetext{
${ }^{14}$ Loi portant code de la couverture médicale de base, https://www.cnss.ma/sites/default/files/ loi-65-00-amo_0.pdf. Accessed 26 March 2020.

${ }^{15}$ List of benefits in kind: http://www.anam.ma/lagence/presentation/la-couverture-medicale-debase/ramed/ prestation-couverte/. Accessed 26 March 2020.

${ }^{16}$ Vulnerable people in urban areas are recognized as having a weighted income of more than DH 3767 per person per year and DH 5650 per person per year and rural residents whose heritage score is greater than 28 and less than or equal to 70 which corresponds to $120 \mathrm{DH}$ per person and capped at $600 \mathrm{DH}$ per household and a non-contributory part financed by taxes, reserved for the poor (Persons whose income is less than or equal to DH 3767 per person per year when they live in an urban area, or whose heritage score is less than or equal to 28 , are recognized as being in a poverty situation.)

17 "La protection sociale au Maroc "Rapport du conseil Economique, Social et Environnemental, 2018, http://www.ces.ma/Documents/PDF/Auto-saisines/2018/AS34-2018/Av-AS34-VF.pdf. Accessed 26 March 2020.
} 


\subsubsection{Pensions}

Four different plans provide retirement benefits to public and private sector employees (national citizens and foreigners) in Morocco: the CNSS, the CMR, the RCAR and the CIMR. ${ }^{18}$ The largest pension fund is CNSS, with 3.2 million affiliates. The eligibility conditions for claiming old-age pensions differ from one pension fund to another. For CNSS, these conditions include: having reached the age of 60 (or 55 for minors who have worked underground for at least 5 years); having ceased all salaried activity; and having contributed at least 3240 days. The minimum pension is 1000.00 dirhams per month. ${ }^{19}$ The amount of the pension corresponds to $50 \%$ of the monthly salary capped for those who totalize at least 3240 days of contribution (around 10 years). This amount is increased by $1 \%$ for each additional insurance period of 216 days ${ }^{20}$ The maximum is $70 \%$ of the average monthly salary. All taxable employees, whether Moroccan or foreign residents, are entitled to this pension, provided they have made sufficient contributions. There is therefore no differential treatment based on the nationality of the employee.

In the public sector, the CMR and the RCAR provide pensions on the basis of a contributory pillar. The required period of contribution is 10 years for CMR and 3 years for RCAR, respectively. The minimum pension for affiliates having the required contribution is 1500 dirhams in both schemes. For CMR, the benefits and contribution are not capped and the contribution rate is $28 \%$ (14\% employee, $14 \%$ state) after the 2016 reform. ${ }^{21}$ The 2016 reform also changed the retirement age from 60 to 63 years gradually from 2016 to 2020. At RCAR, contributions are capped $^{22}$ and the threshold for a contribution salary in 2017 was 17,100 dirhams. The normal contribution period is 30 years and the legal retirement age is 60 years. Each year of contribution entitles to $2 \%$ of average career salary. The maximum pension to which an affiliate is entitled to equals $80 \%$ of the average career salary. The contribution rate is $18 \%$ (6\% the employee and $12 \%$ the employer). The condition for accessing these two pension schemes are the same for nationals and foreigners.

\footnotetext{
${ }^{18}$ However, a draft law (99-15) provides for the establishment of a pension system for nonemployed workers, which will come into force once published in the Official Bulletin. The law, which is likely to affect 11 million people, provides that the independent pension plan is managed by the CNSS and operates in points.

${ }^{19} \mathrm{CNSS}$ activity report 2016, https://www.cnss.ma/sites/default/files/files/CNSS\% $20 \%$ \% 20

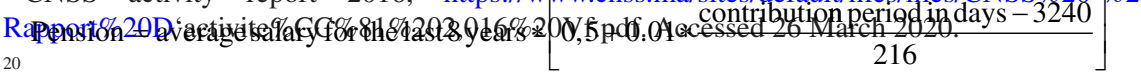

${ }^{21}$ www.courdescomptes.ma/upload/MoDUle_20/File_20_466.pdf. Accessed 26 March 2020.

${ }^{22}$ Each year the threshold are published here: https://www.rcar.ma/?q=fr/indicateurs/salaires-plafond. Accessed 26 March 2020.
} 
In addition to these three plans, Morocco also implemented a survivor pension scheme allocated to family members ${ }^{23}$ of an insured person who, at the time of death, was receiving an old-age pension or was eligible to receive it.

Old-age pensions are exportable. If affiliates decide to live abroad, their acquired rights are transferred to the new country of residence. CNSS also conducts yearly life control operations.

\subsubsection{Family Benefits}

In Morocco, child benefits financing is the responsibility of the employer. These benefits are intended for employees who reside in Morocco and exercise an activity subject to the social security scheme or pensioners with children born no later than 300 days after the effective date of the pension (regardless of their nationality). To qualify for the benefits, insured individuals must have 108 days of contributions during a period of six months of registration and a monthly salary greater than or equal to $60 \%$ of the minimum wage. The amount of child benefits is flat-rate. Since 2007, child benefits are paid directly to the insured. There is a residency condition for children in order to open access to those benefits that are granted independently of the nationality of the beneficiaries, but are non-exportable. Hence, national citizens residing abroad cannot claim this type of benefits from Morocco. Furthermore, CNSS periodically conducts legal control operations aiming to check if children entitled to family benefits continue to meet the living, schooling, or learning conditions.

Regarding maternity benefits, salaried women who cease all wage activity for child birth receive a daily allowance for 14 weeks. The condition for granting this benefit is to have contributed two months during the last 10 months. The amount of the benefit is $100 \%$ of the average daily wage (capped). It is exportable if the affiliate decides to reside abroad, although she has to show a residency certificate in the country she is moving to.

Morocco does not have yet specific schemes of paternity or parental benefits. However, it offers some targeted programs for children and families in vulnerable situations. Yet, these schemes exclude foreign residents, as they are exclusively dedicated to Moroccan citizens. Examples in this regard are the cash transfer programs for children in precarious situations, such as the program for direct assistance to vulnerable widowed women with orphaned children set up in 2014. Financed by a social cohesion support fund, the Family Care Fund pays the widow, for each orphan child under 21 years of age (with the exception of disabled children for whom there is no age limit), an amount of 350 dirhams per month, with a monthly ceiling not exceeding 1050 dirhams monthly per family and subject to schooling or

\footnotetext{
${ }^{23}$ This includes dependent spouses and children under the age of 16, 21 (if they continue their studies) or 18 (if they are apprenticed) or dependent children with disabilities without a stable income regardless of their age.
} 
child's registration in vocational training. Likewise, the Fund provides divorced poor women and their children (when the father is absent or insolvent) an alimony advance of the same amount and with the same ceiling as that granted for the direct assistance program for widowed women in precarious situations. There are also additional programs for the education of children in need. ${ }^{24}$

\subsubsection{Guaranteed Minimum Resources}

There is no specific scheme of non-contributory guaranteed minimum income in Morocco. Only the members of the liberation army can receive a lump sum allowance from CMR that could be considered a minimum income. However, this represents a special category, and the benefit cannot be granted on the basis of volunteering or membership in the fund.

Also, the compensation fund in Morocco is an opportunity to overhaul the social protection system. The compensation system was created in the 1940s to protect the purchasing power of the population and allow them to have access to basic necessities (sugar, flour, soft wheat, butane gas). Until 1973, the compensation fund played a real equalization role by financing subsidies from its own resources, particularly from the oil sector. After 1973, the fund was deprived of its own revenue, entirely dependent on the state budget, thus reducing it to a mere subsidy fund.

\subsubsection{Obstacles and Sanctions}

Foreigners residing in Morocco may be affiliated to existing social protection schemes provided they are employees. In accordance with the provisions of Article 516 of the Labour Code Law 65.99, ${ }^{25}$ any employer wishing to recruit a foreign employee must obtain an authorization from the Government Labour Administration. This authorization is granted in the form of a visa affixed to the work contract. This formality is mandatory and the Labour Code stipulates penalties in case of omission:

\footnotetext{
${ }^{24}$ For instance, the "Tayssir" program is a conditional cash transfer for households living in the poorest communes, aiming to combat dropping out of school. The scheme is currently carried out by municipalities and benefits all rural communes with a poverty rate higher than $30 \%$ and a school dropout rate higher than $8 \%$. Also, the Royal Initiative "One Million Schoolbags" aims to fight against school dropout and inequalities by allowing reduced tuition fees for families of millions of primary schools in rural and urban areas and colleges in rural areas. The Ministry of National Education and Vocational Training also distributes schoolbag kits (bags, books, booklets, school supplies) according to the school level and the environment. With an annual budget of 400 million dirhams in 2013-1014, this initiative has benefited 3,897,542 children aged 6 to 15 , including $2,401,432$ from rural areas.

${ }^{25}$ www.droit-afrique.com/upload/doc/maroc/Maroc-Code-1999-du-travail.pdf. Accessed 26 March 2020.
} 
the employer risks a fine and must pay the repatriation costs of the employee who has not obtained the required work visa or its renewal. For its part, the unauthorised employee cannot work legally and remain in the Moroccan territory. Employment contracts concerning foreigners must be of an indefinite duration. Thus, the affiliation to the social security scheme does not, in any case, affect a foreigner's application for temporary and permanent residency, family reunification, or citizen application.

\subsubsection{Bilateral and Multilateral Social Security Agreements}

Morocco has signed bilateral social security agreements with 15 countries (Algeria, Belgium, Canada, Denmark, Germany, Egypt, Spain, France, Libya, the Netherlands, Luxembourg, Portugal, Quebec, Romania, Sweden, Tunisia). Moroccans who have worked in these countries and immigrants from these countries residing in Morocco can totalise the periods worked to access contributory old-age and invalidity pensions. National citizens residing in these countries can claim these benefits without returning in Morocco. Morocco is also part of three regional integration organisations, but none of them has made any progress towards the social security coordination between the member states or facilitated access to social benefits for Community migrants. Furthermore, as previously mentioned, social security benefits that are subject to transportability are paid to affiliates even if there is no bilateral social security agreement between Morocco and the country of residence. The only condition is to prove a residence certificate.

\subsection{Conclusions}

This chapter has examined the social protection system in Morocco and the access of national residents, non-national residents and non-resident nationals in the field of social insurance, social assistance, health, family benefits, employment and social action plans. As a general rule, the access to social benefits in Morocco is reserved for affiliates- nationals or foreigners without distinction. Current laws (laws 98-15 and 99-15) provide for the extension of retirement and health benefits to non-salaried workers in the future. This highlights the momentum in which the government has been working since 2002 to make social protection more accessible to different social categories of Moroccans and foreign residents through the extension of health benefits to migrants at first. The current social protection system is too fragmented and involves a large number of actors whose coordination is not yet developed. Through the many bilateral agreements put in place between Morocco and its partners, Moroccans living abroad have access to more and more social benefits like retirement pensions and disability fringe benefits even if the question of the transportability of other contributory benefits needs to be addressed. 
Acknowledgements This chapter is part of the project "Migration and Transnational Social Protection in (Post)Crisis Europe (MiTSoPro)" that has received funding from the European Research Council (ERC) under the European Union's Horizon 2020 research and innovation programme (Grant agreement No. 680014). In addition to this chapter, readers can find a series of indicators comparing national social protection and diaspora policies across 40 countries on the following website: http://labos.ulg.ac.be/socialprotection/.

\section{References}

OECD. (2017). Talents à l'étranger : Une revue des émigrés marocains. Paris: OECD Publishing. https://doi.org/10.1787/9789264264304-fr.

Reimat, A. (1997). Les retraités et l'économie : Une mise en perspective historique XIXè- XXè siècles. Paris: L'Harmattan.

Open Access This chapter is licensed under the terms of the Creative Commons Attribution 4.0 International License (http://creativecommons.org/licenses/by/4.0/), which permits use, sharing, adaptation, distribution and reproduction in any medium or format, as long as you give appropriate credit to the original author(s) and the source, provide a link to the Creative Commons license and indicate if changes were made.

The images or other third party material in this chapter are included in the chapter's Creative Commons license, unless indicated otherwise in a credit line to the material. If material is not included in the chapter's Creative Commons license and your intended use is not permitted by statutory regulation or exceeds the permitted use, you will need to obtain permission directly from the copyright holder. 